\title{
MENELISIK KINERJA GOVERNANCE DI DAERAH OTONOMI KHUSUS PAPUA BARAT
}

Ivan Giddeon Fanggidae ${ }^{1}$, Hidayatul Fajri ${ }^{2}$, dan Pandhu Yuanjaya ${ }^{3}$

\begin{abstract}
The implementation of special autonomy in West Papua province aims to increase the development. Centralized development has brought the people of West Papua in a slump multidimensional. The purpose of this article describes the governance performance that the implementation of special autonomy in failure. This article used a qualitative approach. Source of data used comes from RKPD West Papua Province, Public Welfare Indicators (BPS), IGI (parnership), and TKED (The Asia Foundation). The main findings in this article was not prosperous West Papua still has even though the special autonomy fund and the exploitation of natural high. The main indicators are still at the education and welfare of the lowest rankings in Indonesia. Performance Governance and the worst is in the government bureaucracy. This led to the existing resources can not be the welfare of society as stalled in bureaucracy and government.
\end{abstract}

Keywords: Special Autonomy Funds, Governance Performance, and West Papua

\begin{abstract}
ABSTRAK
Implementasi otonomi khusus di Provinsi Papua Barat bertujuan untuk meningkatkan laju pembangunan. Pembangunan yang sentralistis telah membawa masyarakat Papua barat dalam keterpurukan multidimensi. Tujuan artikel ini yaiu menggambarkan kinerja governance karena kenyataan bahwa implementasi otonomi khusus menemui kegagalan. Artikel ini menggunakan pendekatan kualitatif. Sumber data yang digunakan berasal dari RKPD Provinsi Papua Barat, Indikaor Kesejahteraan Rakyat (BPS), IGI (Parnership), dan TKED (The Asian Fondation). Temuan utama dalam artikel ini yaitu Papua Barat masih tidak sejahtera walupun telah emndapatkan dana otonomi khusus dan eksploitasi hasil alam yang tinggi. Indikator utama yaitu pendidikan dan kesejahteraan masih pada peringkat terbawah di Indonesia. Kinerja Governance terburuk ada pada birokrasi dan pemerintah. Hal ini menyebabkan sumberdaya yang dimiliki tidak dapat mensejahterakan masyarakat karena terhenti pada birokrasi dan pemerintah.
\end{abstract}

Kata kunci: Dana Otonomi Khusus, Kinerja Governance, dan Papua Barat

\footnotetext{
${ }_{1}$ Peneliti, Dedikasi Institute. email: gidexfanggidae@gmail.com

2 Dosen, Universitas Aisyah Yogyakarta. email: fajri2889@yahoo.co.id

${ }^{3}$ Dosen, Universitas Negeri Yogyakarta. email: pandhu@uny.ac.id
} 


\section{PENDAHULUAN}

Implementasi dana otonomi khusus di Provinsi Papua Barat telah berjalan selama tujuh tahun terakhir. Dengan begitu, berarti Provinsi Papua Barat telah menerima dana mencapai Rp. 11,070 triliun selama tahun 2009 hingga tahun 2015 (Badan Pusat Statistik, 2015; Keuangan Kementerian, 2014; APBD Provinsi Papua Barat, 2016). Alokasi dana tersebut merupakan amanat UU Nomor 35 Tahun 2008 sebagai landasan hukum atas pelaksanaan otonomi khusus bagi Provinsi Papua Barat. Dana tersebut bertujuan untuk memenuhi kebutuhan dan hak dasar sekaligus mengurangi kesenjangan yang terjadi pada hampir semua sektor, terutama dalam bidang pendidikan, kesehatan, ekonomi, kebudayaan dan sosial politik antara daerah papua dengan daerah lain (King, 2004). UU tersebut juga menegaskan Provinsi Papua Barat memiliki kewenangan khusus untuk mengatur dan mengurus kepentingan masyarakat setempat menurut prakarsa sendiri berdasarkan aspirasi dan hak-hak dasar masyarakat.

Dalam kenyataanya, setelah sembilan tahun Otonomi Khusus berjalan, belum banyak kemajuan berarti yang dirasakan masyarakat Papua Barat. Dengan kata lain, otonomi khusus yang selama ini diimplementasikan justru menghasilkan dampak yang asymetris bila dibandingkan dengan pelaksanaan otonomi daerah di propinsi-propinsi lain. Masyarakat Papua Barat tetap hidup di tengah konflik politik dan keterpurukan ekonomi sosial.

Diberlakukannya otonomi khusus sebenarnya menjadi kesempatan emas bagi masyarakat papua untuk mengatur diri sendiri (Joku, 2007). Hal ini karena masyarakat lokal bisa menentukan tujuan bersama dengan proses bottom up seiring dengan penguatan demokrasi yang dilakukan. Begitu juga bagi pemerintah provinsi dan tentu juga bagi kabupaten/kota di Papua Barat, selain sebagai entry point yang strategis dalam menguatkan pemerintahan daerah, otonomi khusus juga diharapkan dapat menyelesaikan persoalan-persoalan di Provinsi Papua terutama masalah kesejahteraan masyarakat, bukan hanya bertujuan meredam konflik (Mollet, 2011; Webb-Gannon, 2014)

Ditengarai berbagai kebijakan tersebut dalam implementasinya justru semakin meningkatkan ketergantungan daerah dan masyarakat Papua terhadap Pemerintah Pusat. Implikasinya jelas, kebijakan tersebut kurang merangsang semangat lepas dari kemiskinan, masyarakat tertekan oleh tekanan nilai 
tradisional namun terjebak dalam nilai modernisasi, serta kurang memperhatikan potensi dan kapasitas masyarakat lokal sebagai pelaku pembangunan. Pada akhirnya, banyak terjadi masyarakat yang tetap miskin, pembangunan dianggap gagal, birokrasi dianggap tidak mampu menciptakan pelayanan hak-hak dasar dan kinerja yang baik bagi publik. Di sinilah peranan governance secara teoritis dan praktis diperlukan dalam rangka menciptakan aturan tata kelola yang baik. Konsep governance mendorong hubungan yang sinergis dan konstruktif antara negara, sektor swasta dan civil society (United Nations Development Program (UNDP), 1997). Secara tegas Milward dan O'Toole (2009) memberikan interpretasi governance dalam dua aras penting yaitu: governance sebagai studi tentang konteks struktural dari organisasi atau institusi pada berbagai level (multi layered structural contex) dan governance sebagai studi tentang network yang menekankan pada peran beragam aktor sosial dalam sebuah jejaring negosiasi, implementasi, dan pembagian hasil. Peran pemerintah akan bergeser dari penyedia layanan dan barang menjadi lembaga pendorong terciptanya lingkungan yang mampu memfasilitasi pihak lain di komunitas, atau pemerintah hanya sebagai katalisator.
Pemerintah selama ini lebih banyak dilihat sebagai aktor tunggal yang diharapkan banyak pihak untuk memperbaiki kondisi suatu masyarakat dimana pemerintah itu berada. Hal tersebut tidak sepenuhnya salah karena memang masyarakat mengangggap bahwa pemerintah adalah organisasi publik terbesar yang memiliki legitimasi, dana, resources, otoritas, dan aparatur yang sangat besar. Namun seiring dengan prinsip demokrasi, wacana peran pemerintah sebagai aktor tunggal telah digeser oleh wacana governance (Jessop, 2000). Sehingga artikel ini akan berfokus pada analisis perbandingan antara governance secara konseptual dengan praktiknya di Provinsi Papua Barat. Serta juga melihat kinerja governance di Papua Barat di dalam mengelola dana otonomi daerah sebagaimana tujuan dari otonomi daerah, khususnya sebagai upaya peningkatan kesejahteraan masyarakat.

\section{METODE}

Penelitian ini merupakan penelitian kualitatif. Penelitian ini menggunakan Sumber data diperoleh dari hasil laporan pemerintah dan institusi resmi lainnya. Data tersebut diantaranya:

1. RKPD Provinsi Papua Barat 2016 yang membrikan data resmi dari Pemerintah Provinsi Papua Barat. 
2. Indikator Kesejahteraan Rakyat Provinsi Papua Barat 2014 (BPS, 2015). Data ini sebagai sumber komprehensif dalam melihat kesejahteraan masyarakat Provinsi Papua Barat.

3. Indonesian Governance Index (Partnership, 2016). Data yang dikeluarkan Partnership atau Kemitraan memiliki fokus yang sama dengan tulisan ini.

4. Laporan Tata Kelola Ekonomi Daerah (TKED) 2011, merupakan hasil kerjasama antara Komite Pemantauan Pelaksanaan Otonomi Daerah (KPPOD) dan The Asia Foundation.

Analisa data adalah kegiatan mengubah data hasil penelitian menjadi informasi yang dapat digunakan untuk mengambil kesimpulan dalam suatu penelitian. Adapun analisis data yang digunakan dalam penelitian ini menggunakan analisis deskriptif dan analisis komparasi berbagai data yang digunakan. Analisis lebih fokus pada masalah kesehatan dan pendidikan yang menjadi urusan wajib dan memiliki urgensi paling tinggi di wilayah tertinggal.

\section{HASIL DAN PEMBAHASAN}

Papua Barat: Masih Tertinggal dan Tidak Sejahtera

Banyak uang tetap miskin. Itulah yang terjadi di Papua Barat. Otonomi khusus justru menghasilkan dampak yang asymetris bagi Papua Barat. Kemiskinan tetap ada pada rentang 250.000-an jiwa dari 828.000 jiwa masyarakat Papua Barat, walupun dana otonomi khusus selalu meningkat tiap tahunnya (RKP Papua Barat, 2016). Namun, banyak juga yang menganggap Papua Barat telat di perhatikan, atau sejak dulu tidak diperhatikan. Sejak, Papua barat bergabung dengan Indonesia tahun 1962, rezim Suharto, presiden yang berkuasa selama 32 tahun, pemerintah pusat sangat fokus pada pembangunan ekonomi di wilayah barat Indonesia, dengan perhatian kecil pada pembangunan wilayah timur terutama tanah Papua. Hal ini menjadi menyebabkan ketidakmerataan pembangunan ekonomi, daerah seperti Jakarta menjadi maju dan sebaliknya yang terjadi di daerah lain. Pemerintah Suharto juga memperkenalkan kebijakan ekploitasi sumberdaya alam di Papua Barat dengan mengedepankan investasi dan ekploitasi dari perusahaan asing. Perusahaan-perusahaan tersebut memberikan kontribusi yang signifikan bagi pembangunan nasional, namun hanya 
memberikan dampak minim bagi sumber daya perairan dengan kesejahteraan masyarakat lokal. keanekaragaman hayatinya.

Kemiskinan di papua Barat sangat tinggi, yang miris bila dibandingkan dengan daerah lain di Indonesia. Banyaknya migran ke Papua Barat juga membuat kesempatan bekerja bagi masyarakat lokal sangat tipis.

Provinsi Papua Barat memiliki kondisi geografi dan demografi yang unik, dimana penduduknya berada di kawasan yang tidak mudah untuk dijangkau. Dengan luas wilayah mencapai 97.024,27 $\mathrm{Km}^{2}$, jumlah penduduk Papua Barat tahun 2013 hanya sebesar 828.293 jiwa atau berkontribusi sekitar 3,31 persen terhadap total penduduk nasional. Hal tersebut berarti kepadatan penduduk hanya 8,54 jiwa/Km2 dengan sebaran penduduk menurut kabupaten/kota masih dominan di daerah perkotaan yaitu di Kota Sorong $(25,58 \%)$ dan Kabupaten Manokwari $(18,13 \%)$. Disisi lain, pedesaan sebagai tempat tinggal mayoritas masyarakat Papua Barat, ternyata menjadi penyumbang angka kemiskinan mencapai 94,51 persen dari total penduduk miskin sebesar 234,230 jiwa atau 26,67 persen total penduduk. Kondisi ini sangatlah kontras bila dikorelasikan dengan sumber daya alam yang dimiliki, seperti komoditas hutan produksi baik kayu dan non kayu, pertambangan dan energi, serta

\section{Ekonomi Papua Barat sebagian} besar berbasis eksploitasi terhadap sumber daya alam. Eksploitasi dalam pertambangan, gas, oli, dan perikanan telah dimulai sejak tahun 1970-an. Hal tersebut seharusnya mendorong tingginya pertumbuhan ekonomi, pertumbuhan penduduk, tabungan masyarakat dan terjadinya deversivikasi ekonomi di Papua Barat (McGibbon, 2004). Dalam kenyataanya masyarakat Papua Barat tetap hidup di tengah konflik politik dan keterpurukan ekonomi sosial. Secara garis besar, Papua Barat sampai saat ini seperti sangat sulit keluar dari lingkaran setan kemiskinan dan jerat korupsi. Kondisi Paradoks Papua ini merupakan problem yang kompleks dimana pendekatan keamanan dan politis bukan lagi solusi yang tepat bagi masyarakat Papua Barat.

Blair dan Phillips (2003) dalam penelitian yang dilakukan pada tahun 2003 menyebutkan bahwa Papua secara umum mempunyai sumber daya alam yang berlimpah. Namun demikian, wilayahnya tidak bertumbuh dan aktivitas ekonomi yang dihasilkan belum memberikan kontribusi besar pada pembangunan ekonomi yang menguntungkan penduduk asli Papua. Terlepas dari semua perbaikan pelayanan 
sosial sejak tahun 1960, sebagian besar penduduk asli Papua masih terlibat dalam aktivitas-aktifitas pencarian nafkah primitif termasuk berburu, memancing dan bertani. Perekonomian di wilayah perkotaan Papua hampir seluruhnya dikuasai oleh pendatang yang bukan penduduk asli Papua.

Prinsip yang utama dari pemberian otonomi khusus adalah untuk mengurangi kesenjangan antara Provinsi Papua Barat dengan provinsi lain, meningkatkan taraf hidup masyarakat di Provinsi Papua Barat, serta memberikan kesempatan kepada penduduk asli Papua Barat untuk turut serta berperan aktif di dalam pengelolaan daerah dalam skema-skema yang memungkinkan. Prinsip-prinsip itu bermuara pada suatu harapan akan terwujudnya masyarakat yang sejahtera.

Bila merujuk pada Penjelasan UU Nomor 35 Tahun 2008, pemberian otonomi khusus sebagai implikasi dari kebijakan dalam penyelenggaraan pemerintahan dan pembangunan yang sentralistik terdahulu belum sepenuhnya memenuhi rasa keadilan, belum sepenuhnya memungkinkan tercapainya kesejahteraan rakyat, belum sepenuhnya mendukung terwujudnya penegakan hukum, dan belum sepenuhnya menampakkan penghormatan terhadap Hak Asasi Manusia (HAM). Dalam regulasi tersebut juga menjelaskan otonomi khusus memberikan kewenangan khusus yang diakui kepada Provinsi Papua Barat untuk mengatur dan mengurus kepentingan masyarakat setempat menurut prakarsa sendiri berdasarkan aspirasi dan hak-hak dasar masyarakat.

Lebih lanjut, otonomi khusus bagi Provinsi Papua Barat diharapkan dapat mewujudkan: (1) pengaturan kewenangan antara Pemerintah Pusat dengan Provinsi Papua yang ideal; (2) pengakuan dan penghormatan hak-hak dasar orang asli Papua serta pemberdayaannya secara strategis dan mendasar; penyelenggaraan pemerintahan yang baik yang berbasis partisipasi, memperhatikan penduduk asli, dan mengedepankan pembangunan yang transparan dan bertanggungjawab; (4) serta pembagian wewenang, tugas, dan tanggung jawab jelas antara badan legislatif, eksekutif, dan yudikatif, serta Majelis Rakyat Papua sebagai representasi kultural penduduk asli Papua yang diberikan kewenangan tertentu (Undang-Undang No 21 Tahun 2001), namun setelah sembilan tahun berjalan belum banyak kemajuan berarti yang dirasakan masyarakat Papua Barat.

Upaya untuk mensejahterakan masyarakat berada dalam konteks yang universal karena berkaitan dengan hakhak hidup manusia, sebagaimana telah 
dilaporkan UNDP menjelang Word Summit for Social Development pada Maret 1995 di Copenhagen. Masalah ini mencakup tujuh unsur perlindungan yakni: 1) Perlindungan ekonomi. 2) Perlindungan makanan. 3) Perlindungan kesehatan. 4) Perlindungan lingkungan. 5) Perlindungan sosial. 6) Perlindungan polusi dan 7) Perlindungan pendidikan. Sehingga dengan meningkatnya performa governance di Papua Barat cita-cita ini bisa dicapai di kemudian hari tanpa banyak menghabiskan sumberdaya ekonomi seperti yang terjadi tujuh tahun terakhir.

Dampak dana otonomi khusus terhadap kesejahteraan masyarakat papua sebenarnya ada, seperti: peningkatan pada angka partisipasi sekolah, angka melek huruf, rata-rata lama sekolah, penambahan infrastruktur kesehatan dan tenaga medis, serta penurunan penduduk miskin (Purwandanu, 2013). Namun, bila dibandingkan dengan rata-rata nasional seperti yang dijelaskan sebelumnya, seakan dana otonomi khusus tidak bermanfaat sedemikan rupa untuk mempercepat laju pembangunan di Papua Barat. Berdasarkan data BPS Papua Barat (2014), mayoritas penduduk yang bekerja terserap di sektor pertanian sebesar 45,28 persen, di sektor industri 20,82 persen dan di sektor jasa sebesar 33,90 persen. Secara umum terlihat bahwa pekerja di Papua Barat lebih dominan bekerja di sektor informal yang mencapai 61,59 persen.

Peningkatan pendidikan di Provinsi Papua Barat tidak bisa dikatakan bagus, wlaupun terus meningkat. Peningkatan Angka Partisipasi sekolah misalnya, data BPS Papua Barat (2014) menunjukkan Angka Partisipasi Sekolah (APS) murni yang tergolong baik adalah Sekolah Dasar sebesar 92,76 persen, sedangkan Sekolah Menangah Pertama (SMP) dan Sekolah Menangah Atas (SMA) hanya 62,29 persen dan 62,29 persen. Sedangkan perguruan tinggi jauh lebih kecil hanya 24,19 persen. Lebih jauh, Indeks Pembangunan Manusia (IPM) Papua Barat berada tahun 2013 pada urutan kedua terendah di Indonesia dengan nilai 61,82. Nilai tersebut tergolong rendah bila dibandingkan dengan rata-rata provinsi di Indonesia sebesar 68,90.

Indeks Pembangunan Manusia (IPM) Papua Barat berada tahun 2013 pada urutan kedua terendah di Indonesia dengan nilai 61,82. Nilai tersebut tergolong rendah bila dibandingkan dengan rata-rata provinsi di Indonesia sebesar 68,90 . IPM tersebut secara nyata menunjukkan lemahnya tata pemerintahan di Papua Barat yang menyebabkan kesejahteraan masyarakat Papua Barat juga rendah bila dilihat dari indikator IPM 
tersebut. Rendahnya IPM merupakan salah satu cermin mengenai masih buruknya pembangunan sumber daya manusia di Papua Barat. Kondisi rendahnya IPM tersebut tentu tidak terlepas dari kurang optimalnya kinerja birokrasi pemerintah sebagai penyedia pelayanan publik. Hal ini menunjukkan bahwa sejak dilaksanakan otonomi khusus di Papua Barat, sedikit sekali perubahan yang terjadi secara signifikan.

Kondisi palayanan kesehatan di Papua Barat juga masih memprihatinkan. Hingga tahun 2013, belum semua daerah memiliki fasilitas kesehatan yang mencukupi. Terdapat beberapa kabupaten seperti di Kabupaten Tambrauw dan Kabupaten Maybrat yang belum memiliki rumah sakit (BPS, 2014). jumlah penduduk Papua Barat tahun 2013 dan jumlah dokter yang tersedia, maka rasio jumlah penduduk terhadap jumlah dokter di Papua Barat adalah sebesar 7.599, atau mengandung makna bahwa satu dokter rata-rata melayani sekitar 7.599 orang.

Jumlah dokter di Papua Barat mengalami penurunan dibandingkan tahun sebelumnya, distribusinya pun belum tersebar dengan alokasi yang baik. Data sementara menunjukkan rasio penduduk terhadap jumlah dokter tahun 2013 meningkat menjadi 7.599 dibandingkan dengan 3.459 ditahun 2012, jika dilihat periode beberapa tahun sebelumnya menunjukkan peningkatan rasio. Artinya terjadi coverage yang lebih buruk dalam hal akan tertanganinya penduduk dengan peningkatan jumlah dokter dimana jumlah penduduk juga mengalami peningkatan.

Rasio penduduk terhadap dokter tertinggi berada di Kabupaten Teluk Bintuni, dimana seorang dokter harus melayani sekitar 14.149 penduduk. Besarnya rasio tersebut jauh lebih besar dibandingkan dengan Kabupaten Fakfak yang memiliki rasio terkecil yaitu sebesar 4.431 penduduk per seorang dokter. Kabupaten Raja Ampat juga memiliki rasio penduduk terhadap dokter tertinggi kedua. Coverage tanggungan seorang dokter di Kabupaten Raja Ampat memang besar, ditambah dengan kondisi geografisnya yang merupakan wilayah kepulauan akan semakin menyulitkan masyarakat untuk menjangkau pelayanan kesehatan. Sedangkan hanya Kabupaten Tambrauw dan Maybrat yang tidak memiliki dokter dan memiliki karakter wilayah terpencil dengan akses transportasi yang sulit pula sehingga tidak seluruh wilayah tersebut dapat terjangkau pelayanan kesehatan. Dampaknya adalah untuk mendapatkan pelayanan kesehatan oleh dokter harus menuju kabupaten terdekat yang memiliki dokter yaitu Kabupaten Sorong. Terpenuhinya 
kebutuhan penduduk akan dokter dan tenaga kesehatan lainnya tidak hanya masalah jumlah, namun juga distribusinya merata disetiap kabupaten sampai ke wilayah terpencil sekalipun.

\section{Kinerja Governance di Papua Barat: Siapa Penyebab Kegagalan Kebijakan?}

Bila melihat kebijakan selain otonomi khusus di Papua Barat, setiap Gubernur memiliki beragam desain dan strategi untuk meningkatkan kondisi kehidupan masyarakat lokal, namun sebagian besar juga tidak berhasil (Mollet, 2001). Padahal, kebijakan-kebijakan khusus diarahkan untuk memperbaiki situasi terutama yang terkait dengan kemiskinan dan keterbelakangan, pelanggaran HAM, dan kinerja tata pemerintahan, seperti: Pemekaran Wilayah, Program Bantuan Langsung Tunai (BLT), Beras untuk Keluarga Miskin (Raskin), Jaminan Kesehatan Masyarakat (Jamkesmas), Bantuan Operasional Sekolah (BOS), dan Program Keluarga Harapan (PKH), Program Nasional Pemberdayaan MasyarakatMandiri (PNPM-Mandiri) dan Program Kredit Usaha Rakyat (KUR) (setneg.go.id). Hasilnya, kemiskinan di Papua Barat masih cenderung stagnan (seperti yang djelaskan sebelumnya) bila dibandingkan dengan provinsi lain atau rata-rata nasional.

Cita-cita itu sejalan dengan suatu proposisi bahwa pemerintah bukanlah wahana yang mampu mengurusi urusanurusan publik yang sebegitu luas itu sendirian. Sehingga menjadi suatu kepercayaan dari kebanyakan pakar dan praktisi bahwa perlunya perlibatan aktif dari stakeholder-stakeholder lain di luar pemerintah, yaitu organ masyarakat sipil dan institutsi swasta. Konsep itu kemudian dikenal dengan nama governance. Dengan memberikan peran yang sebegitu strategis kepada governance sehingga penulis perlu untuk mereview kajian teoritis dari governance itu terlebih dahulu. Rhodes (1996,1997) mengatakan bahwa banyak bentuk dari "term" governance diantaranya; governance digunakan untuk menggambarkan kondisi minimal dari pemerintah (Stoker, 1997), corporate governance (Cadburry Report, 1992), New Public Management (Osborne \& Gaebler, 1992), Good Governance (World Bank, 1992), Socio-cibernatic System (Kooiman, 1993a; Kooiman, 1993b), Network Governance (Kickert, 1993; Metcalfe \& Richards, 1990; Rhodes, 1991), New Public Governance (Osborne, 2010), Multi-level Governance (Hooge \& Marks, 1992), Governance Partnership (Glasbergen, 2007), Collaborative 
Governance (Ansell, 2008), Open Government (yang semuanya dianggap sebagai wujud dari apa yang disebut sebagai bentuk Deliberative Governance (Dryzek, 2010), Sound Governance (Farazmand, 2004), ataupun Democratic governance (Bevir, 2010; March \& Olsen, 1995).

Sehingga berbicara soal konsep governance atau pemerintahan adalah bicara pada konsep yang belum seutuhnya selesai (Bevir, 2010, Peters \& Pierre, 1998) dan memiliki banyak interpretasi (Rhodes, 1996; Rhodes 1997). Memiliki arti yang sama disatu sisi tetapi berbeda disisi lainnya sehingga menghadirkan sisisisi yang saling berkait kelindan (Jessop, 1998). Meskipun tidak memiliki defenisi ideal, Rhodes (1996) mendefinisikan governance sebagai suatu proses atau kegiatan pemerintahan. Selain itu, governance menunjukkan adanya perubahan bentuk dan peran lembaga pemerintah sekaligus mempengaruhi reformasi dari sektor publik (Bevir, Rhodes, \& Weller, 2003). Sehingga, governance bukan saja mengacu pada semua kegiatan yang dilakukan oleh pemerintah tetapi keterkaitan antara apa yang dilakukan oleh pemerintah, pasar, dan network; yang melingkupi keluarga, suku, organisasi formal atau informal baik yang didasari oleh hukum, norma-norma, kekuasaan, atau bahasa (Bevir, 2012) atau lebih dikenal dengan civil society (masyarakat sipil). Model dari governance tadi, apabila diambil simpul persamaan, maka dapat didedahkan dalam 3 (tiga) prinsip utama, yaitu: transparansi, partisipasi, dan kolaborasi (Rogers dan Lindsey, 2012).

\section{Paparan tentang definisi konseptual} itu akan menjadi suatu diskusi yang menghangat apabila dipaparkan dalam tradisi praktis. Di Papua barat yang menjadi fokus dalam artikel ini memberikan refleksi bahwa konsep governance memang belumlah selesai. Sehingga pencarian model yang paling cocok adalah suatu bentuk usaha yang simultan dari perbaikan-perbaikan terhadap kondisi yang ada.

$$
\text { Provinsi Papua Barat, yang }
$$
merupakan daerah pemekaran, masih kurang berhasil di dalam menjalankan fungsi governance-nya. Hasil pengukuran kinerja tata kelola pemerintahan (governance) yang dilakukan oleh Indonesia Governance Index (IGI) (2014) di Provinsi Papua Barat yang meliputi Pemerintah, Birokrasi, Masyarakat Sipil, dan Masyarakat Ekonomi menunjukkan di antara empat arena yang diukur, kinerja Masyarakat Sipil $(5,56)$ dan Masyarakat Ekonomi $(5,19)$ masuk kategori Sedang, sementara yang termasuk dalam kategori 
Cenderung Buruk adalah Pemerintah $(4,33)$ dan Birokrasi $(3,55)$.

Secara garis besar hasil pengukuran IGI itu dapat diintrepetasikan bahwa di Provinsi Papua Barat, pemerintah masih berjalan kurang kontrol dan kurang memperhatikan aturan. Selain itu, dengan konsepsi governance sebagai suatu sinergitas antara banyak pemangku kepentingan, maka sinergi antara berbagai pelaku-pelaku yang ada didalamnya memprioritaskan kesejahteraan dan keadilan masyarakat serta keinginan untuk memperbaiki situasi yang tidak kondusif masih rendah. Lembaga-lembaga publik di Papua Barat masih kurang optimal dalam upaya mengartikulasikan partisipasi masyarakat ke dalam proses kebijakan publik sehingga perlu dibangun kemitraan antara Pemerintah dan masyarakat untuk secara bersama-sama bertanggungjawab terhadap keberhasilan penyelenggaraan pemerintahan dan pembangunan.

Pengukuran yang dilakukan IGI itu juga memperlihatkan bahwa diantara tiga sektor utama di dalam konsep governance (pemerintah, masyarakat sipil, dan swasta) maka sektor pemerintahlah yang memiliki point penilaian paling rendah; pemerintah $(4,33)$, dan birokrasi $(3,55)$ jika dibandingkan dengan dua sektor lainnya. Hal ini mengindikasikan bahwa permasalahan terbesar dalam upaya pemerintah daerah untuk menssejahterakan masyarakat justru dari dalam diri pemerintah itu sendiri. Sehingga, jika penulis mengupayakan sebuah tesis dalam artikel ini, maka menjadi hal yang wajar jika dikatakan penyebab utama kegagalan otonomi daerah di Provinsi Papua Barat adalah pemerintah daerah.

IGI memperlihatkan bahwa performa sektor pemerintah (pemerintah dan birokrasi) nyaris rendah di dalam semua aspek pengukuran. Dari enam aspek yang diukur, sektor pemerintah hanya bagus di dalam efisensi sedangkan partisipasi, fairness, akuntabilitas, transparansi, dan efektivitas sangat rendah. Begitu juga dengan sektor birokrasi, bahkan lebih parah, pada transparansi dan partisipasi berada pada posisi penilaian yang paling minimal (1.00).

Tentu saja ini bukan kabar bagus dalam upaya mewujudkan pengelolaan pemerintahan yang mampu mensejahterakan kehidupan masyarakat. Sebab apabila pemerintah gagal, maka tidak akan ada ekonomi ekstraktif dan politik inklusif yang menjadi prasyarat munculnya kesejahteraan (Acemoglu dan Robinson, 2014). Sektor lainnya, masyarakat sipil dan swasta, tidak akan mampu bekerja sendiri di dalam 
mewujudkan kesejahteraan, bahkan performa mereka pun perlahan-lahan akan tergerus.

Selain itu, untuk mendapatan gambaran yang lebih proporsional tentang performa pemerintah daerah Provinsi Papua Barat. Bila dilihat kinerja pemerintah daerah dari Tata Kelola Ekonomi Daerah (TKED) melalui sembilan indikator, yaitu: 1) Akses Lahan, 2) Infrastruktur Daerah, 3) Perizinan Usaha, 4) Peraturan di Daerah, 5) Biaya Transaksi, 6) Kapasitas dan Integritas Bupati/Walikota, 7) Interaksi Pemda, 8) Program Pengembangan Usaha Swasta (PPUS), 9) Keamanan dan Penyelesaian Konflik, secara umum Pemerintah Provinsi Papua Barat ternyata juga tidak menunjukkan kinerja yang baik.

Meskipun ada beberapa temuan positif dari survei ini diantaranya: (a) pelaku usaha 85 persen menganggap pelayanan perizinan telah efisien, bebas pungli dan kolusi, (b) Bupati/walikota di Papua Barat menempati peringkat 20 teratas mengenai kapasitas dan integritas, serta bupati/walikota sangat dipercaya oleh pelaku usaha (89 persen), 80 persen pelaku usaha juga menggap Bupati tegas terhadap bawahannya yang melakukan tindakan korupsi, dan 90 persen menganggap Bupati memiliki karakter yang kuat, (c) Pemda Papua Barat dianggap menciptakan kesempatan yang sama oleh pengusaha dan memiliki kerjasama dengan pelaku usaha yang baik. Tetapi juga ditemukan banyak hal negatif di Papua Barat, diantaranya: (a) tata kelola infrastruktur, pelayanan yang lambat, (b) walaupun yakin pengurusan perizinan bersih, namun hanya 8 persen pelaku usaha yang mengetahui tentang keberadaan mekanisme pengaduan, (c) pelaku usaha di Papua Barat peling sedikit berpartisipasi dalam PPUS dibanding daerah lain, (d) sangat terkendala dalam distribusi bahan baku dan hasil produksi. Padahal, empat faktor inilah yang merupakan faktor urgent untuk menciptakan kesejahteraan. Secara umum, peringkat nilai keseluruhan dari TKED (2011) dari kabupaten/kota di Papua Barat yang disurvei berturut-turut, yaitu: Kab. Sorong berada di peringkat 5, Sorong Selatan (16), Fakfak (56), Manokwari (66), Kaimana (81), Kota Sorong (199), Teluk Wondama (71,3), dan Teluk Bintuni (241) dari 245 kabupaten/kota di Indonesia.

Seperti yang sudah diuraikan ditas, kinerja governance yang baik diyakini menjadi aspek yang sangat penting dalam mensejahterakan masyarakat. Milward dan O'Toole (2009) menginterpretasi governance dalam dua aras penting yaitu governance sebagai studi tentang 
konteks struktural dari organisasi atau institusi pada berbagai level (multi layered structural contex) dan governance sebagai studi tentang network yang menekankan pada peran beragam aktor sosial dalam sebuah jejaring negosiasi, implementasi, dan pembagian hasil.

Sehingga, kinerja pemerintah lokal sangat ditentukan oleh kualitas network (Klijn, et. al, 2008). Tetapi kegagalan Pemerintah lokal seperti yang telah dipaparkan membuat mereka tidak memiliki kemampuan untuk mengelola berbagai stakeholder yang terlibat. Walaupun, network dapat dibangun dalam berbagai macam cara, tetapi pemerintah tetap menjadi stakeholder yang menentukan di dalam konsep pemerintahan sebagai suatu network.

Meskipun begitu, bukan suatu alasan menjadi pesimis. Dengan menukar titik tumpu pemahaman, maka koreksi terhadap suatu masalah bisa dilakukan dengan lebih tepat sasaran. Inilah yang coba ditawarkan oleh konsep local network governance. Konsep ini pada tataran ideal berupaya untuk secara komprehensif berkolaborasi dalam menyelesaikan masalah publik melalui integrasi peran, serta layanan publik yang diselenggarakan bersama-sama (Span, et. al, 2012). Hal ini membuka kesempatan stakeholder lain untuk ikut berperan aktif di dalam jaringan.

Gambar 1. berikut ini menjelaskan tiga karakteristik peran governance, yaitu; commisioner (top-down process), facilitator (bottom-up process), dan coproducer (gabungan dari keduannya). Tiga karakteristik tersebut dielaborasi dalam sembilan dimensi yang akan mengungkap aktor utama, pengendali mekanisme, penentuan aturan, keselarasan tujuan, ketergantungan antar pihak, penentuan tujuan, pihak yang bertanggungjawab, mengambangkan misi, dan pengawasan hasil. Span et. al (2012)

\begin{tabular}{|c|c|c|c|}
\hline & \multicolumn{3}{|c|}{ Directing typologies by local government } \\
\hline \multirow{9}{*}{$\begin{array}{l}\text { Actor } \\
\text { Steering } \\
\text { Boundaries } \\
\text { Dependency } \\
\text { Alignment } \\
\text { Goal } \\
\text { Responsibility } \\
\text { Vision } \\
\text { Monitoring }\end{array}$} & Executer & Partner & Initiator \\
\hline & Steering by the municipality & Joint steering & Self steering \\
\hline & Fixed boundaries by the municipality & Jointly set boundaries & Boundaries set by the parties \\
\hline & Formal dependency & Informal/formal dependency & Informal dependencies \\
\hline & Alignment by the municipality & Joint alignment & Alignment by the parties \\
\hline & Fixed goals by the municipality & Joint goal formulation & Goal formulation by the parties \\
\hline & Municipal responsibilities & Joint responsibility & Responsibility by the partners \\
\hline & Vision of the municipality & Joint vision formulation & Vision formulation by the parties \\
\hline & Monitoring by the municipality & Joint monitoring & Monitoring by the parties \\
\hline
\end{tabular}

Gambar 1. Tipologi Local Network Governance (Span et. al, 2012) 
menekankan pentingnya memperhatikan dimensi evolusi, ukuran dan keberagaman network untuk menghasilkan kinerja yang tinggi.

Bila menggunakan analisis tersebut diatas, jaringan di Papua Barat dapat menggunakan tipe commissioner. Pemerintah daerah melakukan semua kegiatan dalam pembangunan daerah. Sebagai daerah hasil pemerkaran baru tahun 2009, evolusi jaringan masih muda atau baru. Demikian dengan ukuran jaringan, terlalu luas karena banyak yang ingin terlibat atau intervensinya tinggi, termasuk keberadaan Oganisasi Papua Merdeka (OPM). Keberagaman yang homogen seharusnya dapat dimanfaatkan dengan baik. Jika Pemerintah Papua Barat dapat memanfaatkan peran tersebut, menurut Span, et. al (2012) akan memiliki performa tinggi. Tapi hal tersebut kembali bergentung pada pemerintah daerah, dalam kenyataannya lebih senang untuk mengurus sendiri walaupun kemampuan dan pengetahuan yang kurang.

\section{SIMPULAN}

Kinerja Governance penting untuk dikaji lebih mandalam dalam praktik otonomi daerah. Pemberian otonomi khusus di Papua Barat masih belum menunjukkan hasil yang seharusnya. Masyarakat masih terbelenggu kemiskinan multidimensi. Pendidikan dan kesejahteraan masih pada peringkat terbawah di Indonesia. Jumlah dana yang terus bertambah tiap tahunnya belum dapat mengubah kondisi tersebut. Kinerja Governance terburuk ada pada birokrasi dan pemerintah. Hal ini menyebabkan sumberdaya yang dimiliki tidak dapat mensejahterakan masyarakat karena terhenti pada birokrasi dan pemerintah.

\section{DAFTAR PUSTAKA}

Anonim. 2015. Kinerja Tata Kelola Provinsi Papua Barat. Indonesian Governance Index Partneship

Anonim. Indikator Kesejahteraan Rakyat Papua Barat 2015. BPS Papua Barat.

Anonim. Lampiran Peraturan Gubernur Provinsi Papua Barat Nomor 11 Tahun 2015 Tentang Rencana Kerja Pembangunan Daerah Tahun 2016

Anonim. Tata Kelola Ekonomi Daerah 2011. KPPOD dan The Asian Fondation.

Bevir, M. 2010. Democratic Governance. Princeton. NJ: Princeton University Press

Bevir, M. 2012. Governance: A Very Short Introduction. Oxford, UK: Oxford University Press

Bevir, M., Rhodes, R. A., \& Weller, P. 2003. Traditions of Governance: Interpreting the Changing Role of 
the Public Sector. Public Administration, 1-17

Cadbury Report. 1992. The Report of the Committee on the Financial Aspects of Corporate Governance. London: Gee \& Co

Dennis C. B dan David L. P. 2003. Komisi untuk Indonesia: Perdamaian dan Perkembangannya di Papua.

Dryzek, J. (2010). Foundations and Frontiers of Deliberative Governance. Oxford: Oxford University Press.

Farazmand, A. 2004. Sound Governance: Policy and Administrative Innovation. In A. Farazmand (Ed.), Sound Governance in the Age of Globalization: A Conceptual Framework (pp. 120). Westport, CT: Praeger

Jessop, B. 1998. The Rise of Governance and the Risks of Failure: The Case of Economic Development. International Social Science Journal, 50, 155, 29-4

Joku, Franzalber. 2007. Problem and Procpectus of the Special Autonomy Law. University of Sydney.

King, Peter. 2014. West Papua and Indonesia Since Suharto: Independence, Autonomy, or Chaos?. UNSW Press

Klijn, E. (2005). Networks and Interorganizational

Management: Challenging, Steering, Evaluation and The Role of Public Actors In Public Management. In E. Ferlie, L.
Lynn, \& C. Pollitt (Eds.), The Oxford handbook of public management (pp. 257-281). Oxford, UK: Oxford University Press.

Kooiman, J. 1993. Modern Governance: New Government-Society Interactions. London: Sage Publications

March, J. G., \& Olsen, J. P. 1995. Democratic Governance. New York, NY: Free Press

Marin, B dan Mayntz, R. 1991. Policy Network. Boulder: Westview

Mollet, J.A. 2011. The Dynamics of Contemporary LocalGovernment Policies and Economic Development in West Papua. Development in Practice. 232-243

Osborne, D., \& Gaebler, T. (1992). Reinventing Government. Reading, MA: Addison Wesley

Peters, G., \& Pierre, J. (1998). Governance without Government? Rethinking Public Administration. Journal of Public Administration Research and Theory: J-PART, 8, 2, 223-243

Rhodes, R. A. 1996. The New Governance: Governing without Government. Political Studies, 44, 4, 652-667.

Rhodes, R. A. 1997. Understanding Governance: Policy Networks, Governance, Reflexivity and Accountability. Philadelhia, PA: Open University Press 
Span, et. al. 2012. The relationship Between Governance Roles and performasnce in Local Public Interorganizational Networks: A Conceptual Analysis. The American Review of Public Administration. 42 (2) 186-201. Sage.

Stoker, G. (1997). Hearing but not Listening: The Local Government Review Process in West Sussex. Public Administration, 75, 35-48

Webb-Gannon, Camellia. 2014. Merdeka in West Papua: Peace, Justice and Political Independence. Antropoligica. 